\title{
Production and partial purification of beta- mannanase from Aspergillus niger associated with ilaje lake, Ondo state, Nigeria
}

\begin{abstract}
The present study aimed at the isolation, screening and partial purification of betamannanase from fungi isolated from soil and water samples collected from Ilaje Lake, Ondo state, Nigeria. The associated fungi were isolated and counted by standard microbiological methods. Partial purification of crude mannanase was done by standard biochemical methods. Quantitatively, mannanase production was performed in mineral salt medium into which Locust Bean Gum (LBG) had been incorporated as the sole carbon source. Enzyme activity was determined by dinitrosalicylic acid (DNSA) method, while protein content was evaluated by Lowry's method. The highest fungal counts were recorded for water sample collected from Ilaje Lake with $3.4 \times 10^{8} \mathrm{sfu} / \mathrm{mL}$. The organisms encountered include Aspergillus flavus, Rhizopus stolonifer, A. fumigatus, A. niger, $R$. japonicus, Penicillum italicum, Fusarium solani and Candida albicans. All the fungal isolates encountered from these sources showed varied degrees of mannanase activities. The highest specific mannanase activity was recorded for isolate 4B1, while the lowest value was obtained with isolate 1B2. Purification of crude mannanase from A. niger was carried out by ammonium sulphate precipitation and gel filtration (Sephadex G-200). Fractionation of ammonium sulphate precipitated mannanase from A. niger on Sephadex G-200 produced two activity peaks. In this investigation, fungal isolates evaluated for mannanase production from this source gave appreciable mannanase activity and this could be applied in many industrial processes.
\end{abstract}

Keywords: beta-mannanase, ilaje lake, locust bean gum, fungal counts, partial purification
Volume 5 Issue 3 - 2017

\author{
Oladipo Oladiti Olaniyi, Olajide Adebowale \\ Department of Microbiology, Federal University of Technology, \\ Nigeria
}

\begin{abstract}
Correspondence: Oladipo Oladiti Olaniyi, Department of Microbiology, Federal University of Technology, PMB 704,Akure, Nigeria, Tel +2348068054636, Email microladit@gmail.com
\end{abstract}

Received: May 13, 2017| Published: August 10, 2017

\section{Introduction}

Beta-mannanase otherwise known as mannan endo-1,4- $\beta$ mannosidase or 1,4- $\beta$-D-mannanase with an enzyme commission (EC) 3.2.1.78 breakdowns $\beta$-1,4-mannosidic bonds in the main chain of glucomannans, galactomannans and $\beta$-1,4-mannans. ${ }^{1}$ It transforms the abundant mannan-rich heteromannan, glucomannan and galactomannan substrates into manno-oligosaccharides ${ }^{2}$ and a small amount of mannose, glucose and galactose. ${ }^{1,3}$ A number of plants, bacteria, fungi and various invertebrates had been reported to produce $\beta$-mannanase. ${ }^{1,3}$ The mannanase of biological origins have found a variety of applications in different industrial sectors, ${ }^{3}$ including animal feed formulation, pharmaceutical products preparation, pulp biobleaching, ${ }^{4}$ as well as pre-treatment of plant biomass for second generation biofuel production. ${ }^{5}$

There is a greater demand for biotechnological and industrial stable enzymes with higher catalytic efficiency that can function under harsh environmental conditions. In the recent years, screening and isolation of microorganisms for the production of industrial enzymes of microbial origin with unique and excellence characteristics has become one of the focuses of research in biotechnology. Enzymes required for industrial applications should be stable at high temperature, $\mathrm{pH}$, and presence of salts, solvents, and etcetera. Extracellular enzymes from microbes associated with extreme environments such as halophiles are blessed with higher catalytic power to initiate and sustain metabolic activities under high salt concentrations. Gomes \& Steiner ${ }^{6}$ and Karan \& Khare $^{7}$ have been reported that enzymes from extreme environments are expected to be active and stable under more than one extreme condition.

The physicochemical analysis carried out on four different coastal waters from Ilaje, Ondo state, Nigeria revealed that they were slightly acidic with a mean $\mathrm{pH}$ of 6.69 and also moderately saline with a mean salinity of $16.68 \% .{ }^{8}$ Hence, mannanase obtained from bacteria isolated from this source are expected to be halotolerant. Mannanaseproducing microorganisms have been reported from different sources but there has been scanty or no information on mannanase production from bacteria inhabits Ilaje Lake. Hence, enzymes from haloterant bacteria from this location should have an edge in terms of stability. In search of high performance mannolytic organisms; we isolated and screened different fungi from soil and water samples in Ilaje, Ondo State, Nigeria. Therefore, the present study dealt with the isolation and screening of fungal isolates for beta-mannanase production and its partial purification from Aspergillus niger.

\section{Materials and methods}

\section{Sources of Sample}

Water and soil samples were collected from Ilaje Lake, Ondo State, Nigeria in sterile bottles. The samples were transferred to the laboratory and were used as sources for the isolation of mannanaseproducing fungi. ${ }^{9,10}$ 


\section{Isolation and identification of mannanase-producing fungi from soil and water samples}

The total fungal counts from the samples were determined using the pour plate method on potato dextrose agar. The samples were serially diluted and $1 \mathrm{ml}$ of an appropriate dilution was used to inoculate the plate in duplicate. The plates were incubated at $28 \pm 2^{\circ} \mathrm{C}$ for $72 \mathrm{hrs}$, after which the total colony count was determined as previously described. ${ }^{11}$ At the end of incubation, the colonies were sub-cultured from the mixed cultures and identified on the bases of cultural characters (colour, shape of colony, surface and reverse pigmentation and texture of the colony) as well as microscopic structure (septate or nonseptate hyphae, structure of hyphae and conidia). ${ }^{12}$

\section{Screening of mannanase-producing fungi in submerged state fermentation}

Medium composition described by Mandles \& Weber ${ }^{13}$ modified by Arotupin \& Olaniyi ${ }^{10}$ was used for submerged fermentation (static condition). The basal medium contained $(\mathrm{g} / \mathrm{L})$ : $\mathrm{LBG} 10 \mathrm{~g}$, peptone $2 \mathrm{~g}$, yeast extract $2 \mathrm{~g}, \mathrm{NaNO}_{3} 2 \mathrm{~g}, \mathrm{KH}_{2} \mathrm{PO}_{4} 1 \mathrm{~g}, \mathrm{mgSO}_{4} .7 \mathrm{H}_{2} \mathrm{O} 0.5 \mathrm{~g}, \mathrm{KCl} 0.5 \mathrm{~g}$ and $\mathrm{FeSO}_{4} .7 \mathrm{H}_{2} \mathrm{O}$ traces. The $\mathrm{pH}$ of the media was adjusted to 6.8 with $\mathrm{pH}$ meter (Denver Instrument, Model $20 \mathrm{pH} /$ Conductivity meter) prior sterilization. Then, $100 \mathrm{~mL}$ of the liquid medium was dispensed in $250 \mathrm{~mL}$ Erlenmeyer flask and sterilized at $121^{\circ} \mathrm{C}$ for 15 minutes. The sterile basal medium was inoculated with 2 discs of $8 \mathrm{~mm}$ diameter of the fungal strains from PDA using cork borer. The inoculated media were incubated at $30^{\circ} \mathrm{C}$ for 5 days at static condition. Crude enzyme preparation was obtained by centrifugation at $6000 \mathrm{rpm}$ for 10 minutes at $4^{\circ} \mathrm{C}$ using refrigerated ultracentrifuge (Centurion Scientific Limited). The supernatant was used as the crude extracellular enzyme source. Each treatment was carried out in triplicates and the results obtained throughout the work were the mean of at least 3 experiments.

\section{Enzyme assay and protein determination}

Mannanase activity was assayed in the reaction mixture comprising of $0.5 \mathrm{~mL}$ of $1 \% \mathrm{LBG}$ prepared in $50 \mathrm{mM}$ potassium phosphate buffer $\mathrm{pH} 6.8$ and $0.5 \mathrm{~mL}$ of supernatant at $45^{\circ} \mathrm{C}$ for 60 minutes (modified method of El-Naggar et al. ${ }^{14}$ ). At the end of the incubation period, tubes were removed from the water bath (Lamfield Medical England Model DK-600), and the reaction was terminated by the addition of $2 \mathrm{~mL}$ of 3,5-dinitrosalicylic acid (DNSA) reagent per tube. The tubes were incubated for 5 minutes in a boiling water bath for colour development and were cooled rapidly. The activity of reaction mixture was measured against a reagent blank at $540 \mathrm{~nm}$. Amount of reducing sugar released was determined by the dinitrosalicylic acid reagent (DNS).${ }^{15}$ One unit of mannanase activity was defined as amount of enzyme producing 1 micromole of mannose per minute under the experimental conditions. The amount of protein produced in the basal medium was evaluated according to the method of Lowry et al., ${ }^{16}$ using Bovine Serum Albumin (BSA) as the standard.

\section{Mannanase purification}

Mannanase purification was performed in three stages. In the first stage, the supernatant obtained after centrifugation was precipitated by the addition of ammonium sulphate to achieve $70 \%$ ammonium sulphate concentration. ${ }^{1}$ The precipitated enzyme was then diluted

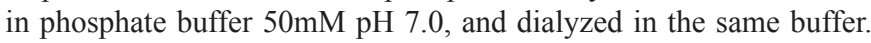
Secondly, the enzyme obtained after dialysis was loaded into ion exchange column chromatography with diethylaminoethyl (DEAE) Sephadex G-200 matrix $(20 \times 2.5 \mathrm{~cm}$, Pharmacia). The fractions obtained were sequentially washed with ion free water and0.01 M Tris-HCl buffer $\mathrm{pH}$ 8.0. The bound protein molecules were eluted with concentration gradient of $\mathrm{NaCl}$. The absorbance of each fraction collected was measured at $280 \mathrm{~nm}$ with UV spectrophotometer (LabTech Digital) and the activity of mannanase of each fraction was determined. In the third stage, concentrated enzyme from second stage purification step was loaded onto the column chromatography $(2.5 \mathrm{~cm}$ in diameter and $30 \mathrm{~cm}$ high) which contained Sephadex G-200 (Pharmacia). The concentrated enzyme was eluted with phosphate buffer $\mathrm{pH} 7.0$ at the flow rate of $20 \mathrm{~mL} / \mathrm{h}$.A fraction of $10 \mathrm{~mL}$ was collected at interval of 30 mins and the absorbance was taken at $280 \mathrm{~nm}$. Fractions with mannanase activity were pooled and concentrated in glycerol solution at $30^{\circ} \mathrm{C}$.

\section{Results}

\section{Populations of mannanase-producing fungi from soil and water samples}

Table 1 shows the total fungal counts from each of the sources. Water sample had the highest number of fungal population of $3.4 \times 10^{8} \mathrm{sfu} / \mathrm{ml}$, while soil sample from Ilaje Lake $\left(2.2 \times 10^{8} \mathrm{sfu} / \mathrm{g}\right)$ recorded the least fungal counts.

Table I Populations of mannanase-producing fungi from soil and water samples

\begin{tabular}{ll}
\hline Sources & Fungal counts \\
\hline ILS & $2.2 \times 10^{8} \mathrm{sfu} / \mathrm{g}$ \\
ILW & $3.4 \times 10^{8} \mathrm{sfu} / \mathrm{ml}$ \\
\hline
\end{tabular}

ILS, soil sample from ilaje lake; ILW, water sample from ilaje lake

\section{Cultural characterization and microscopic observation of fungal isolates}

Table 2 shows the cultural characterization and microscopic observation of fungal isolates associated with soil and water samples from Ilaje Lake. Eight fungal isolates were isolated from the samples. The organisms encountered include Aspergillus flavus, A. fumigatus, A. niger, Rhizopus japonicus, R. stolonifer, Penicillum italicum, Fusarium solani and Candida albicans.

Table 2 Cultural characterization and microscopic observation of fungal isolates

\begin{tabular}{llll}
\hline Isolate code Cultural characteristics & Microscopic observation & Suspected organisms \\
\hline & $\begin{array}{l}\text { An upright conidiophores that } \\
\text { terminates in a davate swelling bearing } \\
\text { IB2 \& Z3E2 }\end{array}$ & $\begin{array}{l}\text { Greenish yellow mycelial growth the apex or radiating } \\
\text { from the entire surface; conidia } \\
\text { are I-celled and globose }\end{array}$ & Aspergillus flavus \\
& &
\end{tabular}


Table Continued....

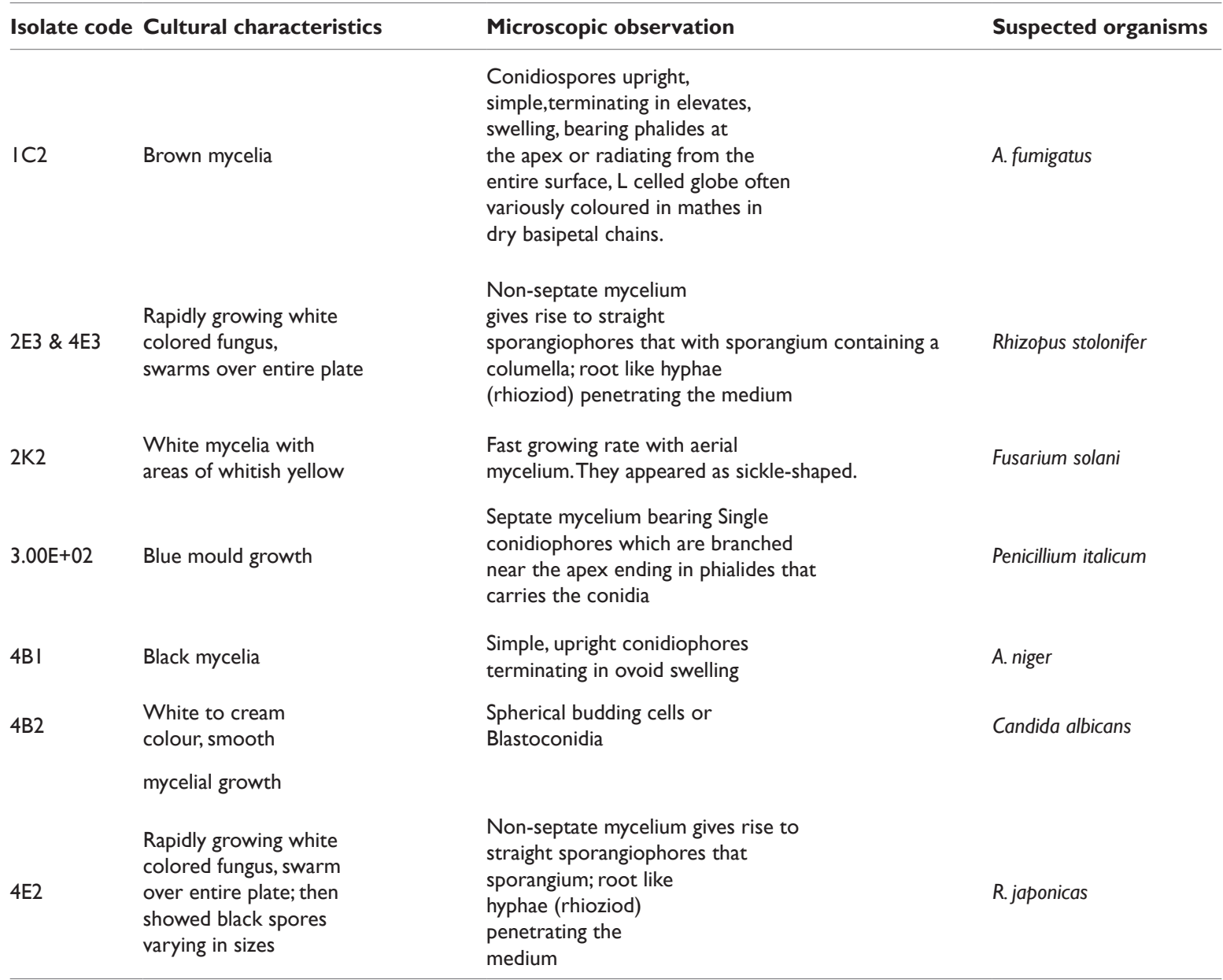

\section{Percentage occurrence of fungal isolates}

Table 3 shows the percentage occurrence of fungal isolates associated with the samples. The highest percentage occurrence of 20\% was obtained for Aspergillus flavus and Rhizopus stolonifer, while Aspergillus fumigatus, A. niger, Rhizopus japonicus, Penicillum italicum, Fusarium solani and Candida albicans had the same value of $10 \%$.

Table 3 Percentage occurrence of fungal isolates

\begin{tabular}{ll}
\hline Fungal isolates & $\%$ Occurrence of isolates \\
\hline Aspergillus flavus & 20 \\
A. fumigatus & 10 \\
Rhizopus stolonifer & 20 \\
Fusarium solani & 10 \\
Penicillium italicum & 10 \\
A. niger & 10 \\
Candida albicans & 10 \\
R. japonicas & 10
\end{tabular}

\section{Mannanase production by fungal isolates from different samples}

The quantitative determination of mannan-degrading enzyme from different fungal isolates is shown in Table 4. All the fungal isolates encountered from different sources displayed varied degrees of mannanase activities. The highest mannanase activity and specific activity of $9.37 \mathrm{U} / \mathrm{mL}$ and $2.59 \mathrm{U} / \mathrm{mg}$ respectively was produced by fungal isolate $4 \mathrm{~B} 1$ sourced from water sample, while the lowest values for mannanase activity and specific activity were obtained from $2 \mathrm{E} 3$ and 1B2 respectively. Protein content ranged from $3.06 \mathrm{mg} /$ $\mathrm{mL}$ to $5.39 \mathrm{mg} / \mathrm{mL}$ was produced by the fungal isolates, with the highest protein content displayed by isolate IB2 obtained from soil sample. Therefore, fungal isolate 4B1 was selected for purification studies because of its highest mannanase-producing potential.

\section{Elution profile of partially purified mannanase on sephadex G-200}

After $25 \%$ ammonium sulphate saturation of crude enzyme, the precipitates were dialyzed against $50 \mathrm{mM}$ phosphate buffer $\mathrm{pH} 6.8$ for 24 hours at $4^{\circ} \mathrm{C}$. Dialyzed protein was loaded onto a Sephadex G-200 column which was eluted with the same buffer. The ammonium sulphate-dialysate fraction on Sephadex G-200 tends to produce two activity peaks represented as A and B (Figure 1). Mannanase activity increased appreciably and reached A with an enzyme activity of $98.09 \mu \mathrm{mol} / \mathrm{min} / \mathrm{mL}$, while peak B had enzyme activity of $148.12 \mu \mathrm{mol} /$ $\mathrm{min} / \mathrm{mL}$ 
Table 4 Mannanase production by fungal isolates from different samples

\begin{tabular}{|c|c|c|c|c|}
\hline \multirow{2}{*}{ Source } & \multirow{2}{*}{ Isolate code } & \multirow{2}{*}{ Mannanase activity $(\mathrm{U} / \mathrm{mL})$} & \multirow{2}{*}{$\begin{array}{l}\text { Protein content } \\
(\mathrm{mg} / \mathrm{mL})\end{array}$} & \multirow{2}{*}{$\begin{array}{l}\text { Specific mannanase } \\
\text { activity (U/mg) }\end{array}$} \\
\hline & & & & \\
\hline \multirow{4}{*}{ ILS } & IB2 & 4.17 & 5.29 & 0.79 \\
\hline & $1 C 2$ & 4.47 & 3.27 & 1.37 \\
\hline & $2.00 \mathrm{E}+03$ & 3.58 & 3.28 & 1.09 \\
\hline & $2 \mathrm{~K} 2$ & 7.13 & 3.3 & 2.16 \\
\hline \multirow{6}{*}{ ILW } & $3.00 \mathrm{E}+02$ & 4.2 & 3.38 & 1.24 \\
\hline & Z3E2 & 6.71 & 3.49 & 1.92 \\
\hline & $4 \mathrm{BI}$ & 9.37 & 3.62 & 2.59 \\
\hline & $4 \mathrm{~B} 2$ & 5.18 & 3.06 & 1.7 \\
\hline & $4 C 3$ & 3.65 & 3.28 & 1.11 \\
\hline & $4.00 \mathrm{E}+02$ & 5.28 & 3.24 & 1.63 \\
\hline
\end{tabular}

ILS, soil sample from ilaje lake; ILW, water sample from ilaje lake

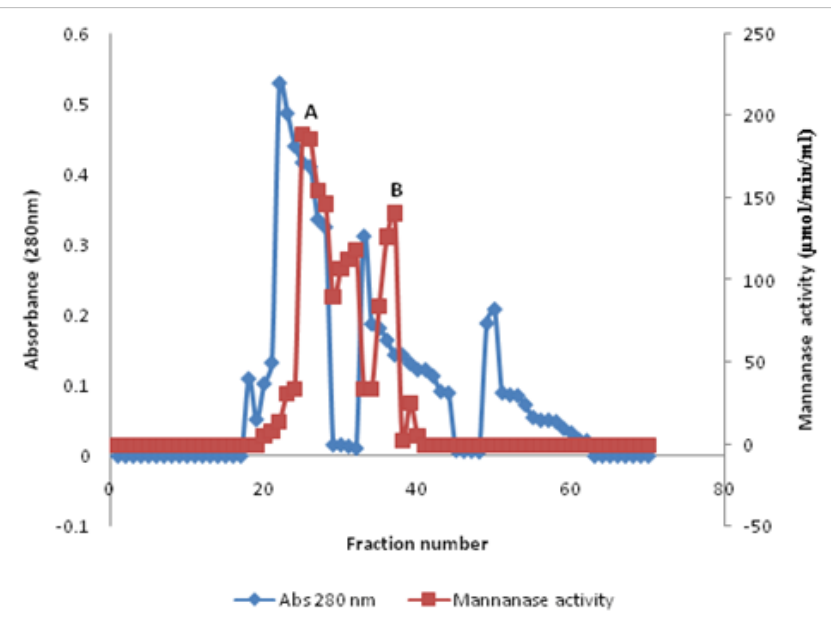

Figure I Elution profile of partially purified mannanase from Aspergillus niger on Sephadex G-200.

\section{Summary of purification procedures}

Three step purification procedures were adopted, and a 7.43-fold purification was achieved with specific activity of $48.06 \mu \mathrm{mol} / \mathrm{min} /$ $\mathrm{mg}$ (Table 5). Enzyme activity increased from $169.13 \mu \mathrm{mol} / \mathrm{min} / \mathrm{mL}$ in crude enzyme to $218.46 \mu \mathrm{mol} / \mathrm{min} / \mathrm{mL}$ after gel filtration. Crude protein and total protein decreased from 26.14 and $3920.46 \mathrm{mg} / \mathrm{mL}$ to 4.55 and $58.18 \mathrm{mg} / \mathrm{mL}$ respectively.

Table 5 Summary of purification of mannanase from Aspergillus niger

\begin{tabular}{|c|c|c|c|c|c|c|c|c|}
\hline Step & Vol. & EA & $\mathbf{C P}$ & TP & TA & SA & Yield & Fold \\
\hline Crude Enzyme & 150 & 169.13 & 26.14 & 3920.46 & 25369.98 & 6.47 & 100 & 1 \\
\hline Ammonium sulphateprecipation & 44.1 & 188.87 & 17.05 & 751.7 & 8328.96 & 11.08 & 32.83 & 1.71 \\
\hline Gel filtration & 12.8 & 218.46 & 4.55 & 58.18 & 2796.34 & 48.06 & $1 \mathrm{l} .02$ & 7.43 \\
\hline
\end{tabular}

EA, enzyme activity $(\mu \mathrm{mol} / \mathrm{min} / \mathrm{mL}) ; \mathrm{CP}$, crude protein $(\mathrm{mg} / \mathrm{mL}) ; \mathrm{TP}$, total protein $(\mathrm{mg} / \mathrm{mL}) ; \mathrm{TA}$, total activity $(\mu \mathrm{mol} / \mathrm{min} / \mathrm{mL}) ; \mathrm{SA}, \mathrm{specific} \mathrm{activity}(\mu \mathrm{mol} / \mathrm{min} / \mathrm{mg})$

\section{Discussion}

Mannanases from Fungi are generally produced into culture medium supplemented with different mannan-rich substrates known as inducers. These include Locust Bean Gum (LBG), guar gum, konjac flour, and copra meal. Also, some microorganisms are capable of secreting considerable volume of extracellular enzymes into their basal media and this property has been adopted for industrial enzyme production.

The high fungal counts from water sample may be due to lack of efficient control measures in the discharge of organic wastes into the water bodies. The excessive addition of organic wastes (nutrients) to water bodies is known to stimulate excessive growth of microorganisms. ${ }^{10}$ 
The fungal isolates obtained from Ilaje lake (water and soil samples) exhibited different mannanase activities in basal media supplemented with LBG as an inducer. The production of mannanase in LBG medium had been reported for Bacillus circulans, Chryseobacterium indologenes, Bacillus sp.mg-33, Bacillus amylolequifaciens 10A1 ${ }^{4}$ Bacillus sp., Aspergillus niger, Sclerotium rolfsii, Trichoderma sp. and Scopulariopsis candida. The secretion of mannanases by these isolates on LBG media could be attributed to the ability of their genetic make up to secrete active mannanase coupled with varied diffusion rate. ${ }^{10}$ All the tested fungal strains were able to produce extracellular mannanase in submerged state fermentation, although with differences in the rate of enzyme production. These differences might be attributed to the source of isolation and slight variation in their genetic makeup. ${ }^{10}$

The variation in protein content generated by each of the strains in submerged state fermentation could be attributed to the production of variety of enzymes (amylases, cellulases, protease and xylanases) in addition to the enzyme been examined in this study. Presumably, the protein from fungal cells and metabolites rich in protein might interfere with mannanase production causing variation in protein contents, since the protein assay could only identify accumulated protein in enzyme production medium. ${ }^{10}$

Preliminary investigations in this study revealed that Aspergillus niger gave the highest mannanase activity out of all the fungal isolates encountered from the lake. It was therefore selected for purification studies. Mannanase has been produced by various microorganisms and purified as reported in previous studies. Olaniyi et al., ${ }^{1}$ produced and purified mannanase enzyme from Penicillium italicum isolated from yam peel. Madau \& Shetati sourced for $\beta-1$, 4-mannanase from Scopulariosis candida and purified it while Sumardi isolated Geobacillus stearothermophilus L07 from oil palm shell, screened for mannanase production after which it was purified. Abdel-fattah purified $\beta$-mannanase from Aspergillus oryzae. The two major activity peaks obtained from the elution profile could be attributed to the source of isolation coupled with environmental influences. ${ }^{1}$

\section{Conclusion}

Aspergillus niger isolated from water sample in Ilaje, Ondo state, Nigeria showed a potential to convert substrates containing mannan into simple carbohydrates which could be readily used in many applications such as animal foods and a feed stock for production of prebiotics. It is recommended that the characterization of the purified $\beta$-mannanase and molecular study should be carried out on the isolate.

\section{Acknowledgements}

None.

\section{Conflict of interest}

The author declares no conflict of interest

\section{References}

1. Olaniyi OO, Arotupin DJ, Akinyele BJ. Kinetic properties of purified $\beta$ mannanase from Penicillium italiticum. British Microbioogy Research Journal. 2014;4(10):1092-1104.

2. Songsiriritthigul C, Buranabanyat B, Haltrich D, et al. Efficient recombinant expression and secretion of a thermostable $\mathrm{GH} 26$ mannanendo-1,4- $\beta$-mannosidase from Bacillus licheniformis in Escherichia coli. Microbial Cell Factory. 2010;9:20.

3. Dhawan S, Kaur J. Microbial mannanases: an overview of production and applications. Critical Review in Biotechnology. 2007;27(4):197-216.

4. Mabrouk MEM, El Ahwany AMD. Production of $\beta$-mannanase by Bacillus amylolequifaciens10A1 cultured on potato peels. African Journal of Biotechnology. 2008;7(8):1123-1128.

5. Wyman CE, Decker SR, Himmel ME. Polysaccharides: Structural Diversity and Functional Versatility. USA: CRC Press Boca Raton; 2005. p. 953-1033.

6. Gomes J, Steiner W. The biocatalytic potential of extremophiles and extrozymes. Food Technology and Biotechnology. 2004;42:223-225.

7. Karan R, Khare SK. Purification and characterization of a solvent stable protease from Geomicrobium sp. EMB2. Environmental Technology. 2010;31(10):1061-1072.

8. Ajibare AO. Assessment of physico-chemical parameters of waters in Ilaje Local Government Area of Ondo State, Nigeria. International Journal of Fishery and Aquatic Studies. 2014;1(5):84-92.

9. Abe J, Hossain ZM, Hizukuri S. Isolation of $\beta$-mannanase producing microorganisms. Journal of Fermentation and Bioengineering. 1994;3:259-261.

10. Arotupin DJ, Olaniyi OO. Screening and identification of mannanaseproducing fungi isolated from selected agricultural wastes. British Microbiology Research Journal. 2013;3(4):635-644.

11. Lateef A, Oloke JK, Gueguim-Kana EB. Antimicrobial resistance of bacterial strains isolated from orange juice products. African Journal of Biotechnology. 2004;3(6):334-338.

12. Mandles M, Weber J. Exoglucanase activity by microorganisms. Advance Chemistry. 1969;95:391-414

13. El-Naggar MY, El-Aassar SA, Youssef AS. Extracellular $\beta$-mannanase production by the immobilization of the locally isolated Aspergillus niger. International Journal of Agriculuture and Biology. 2006;8:57-62.

14. Miller GL. Use of dinitrosalicylic acid reagent for determination of reducing sugars. Analytical Chemistry. 1959;31(3):426-428.

15. Lowry $\mathrm{OH}$, Rosebrough NJ, Farv A. Protein measurement with folin phenol reagent. Journal of Biology and Chemistry. 1951;193:265-275.

16. Dhawan S, Jagdeep K. Microbial mannanases: An overview of production and applications. Crit Rev Biotechnol. 2007;27(4):197-216. 